inOedia $\quad \begin{aligned} & \text { InMedia } \\ & \text { The French Journal of Media Studies }\end{aligned}$

$4 \mid 2013$

Exploring War Memories in American Documentaries

\title{
The War Tapes: Documenting the Iraq War with Digital Cameras
}

\section{Delphine Letort}

\section{Q OpenEdition \\ 1 Journals}

\section{Electronic version}

URL: http://journals.openedition.org/inmedia/729

DOI: 10.4000/inmedia.729

ISSN: 2259-4728

\section{Publisher}

Center for Research on the English-Speaking World (CREW)

\section{Electronic reference}

Delphine Letort, «The War Tapes: Documenting the Iraq War with Digital Cameras », InMedia [Online], 4 I 2013, Online since 18 November 2013, connection on 08 September 2020. URL : http:// journals.openedition.org/inmedia/729; DOI : https://doi.org/10.4000/inmedia.729

This text was automatically generated on 8 September 2020

(C) InMedia 


\title{
The War Tapes: Documenting the Iraq War with Digital Cameras
}

\author{
Delphine Letort
}

1 The spread of digital cameras contributed to shaping the representations of the Iraq war, offering soldiers the means to film themselves in the course of duty and providing Iraqi insurgents with the opportunity to spotlight their acts of resistance. The availability of an Internet network also made it possible for Americans and Iraqis alike to give a first-hand account of their experience of combat (mainly represented by the random explosions of Improvised Explosive Devices) - although the soldiers' videos gained prominence on Youtube. ${ }^{1}$ The Vietnam War had also been filmed by soldiers who brought along super $8 \mathrm{~mm}$ movie cameras and film cartridges on deployment; however, these military filmmakers needed to have their films processed before they could view the taped images, which limited the scope of their filmmaking to candid reporting. The recovered tapes provided archival footage for the twelve films comprised in the Vietnam Home Movies released in the $1980 \mathrm{~s}^{2}$ the study of which highlights the contrast with the new technologies that have democratized the process of filmmaking and increased the soldiers' agency in the making of war images. With their integrated display screens, digital cameras offer immediate access to the recorded footage, turning filmmakers into viewers of the scenes they witness. Using The War Tapes as a case study, I argue that the instantaneity of the process prompts the soldiers to cast a self-conscious look at the events unfolding before their eyes and at their roles in them. The soldiers of the Iraq War assume a critically reflective stance when looking through the viewfinder of their cameras, articulating an analytical discourse that is missing from the Vietnam War tapes.

Critics of the Iraq War emphasize the power of digital cameras, embedded in the vehicles of the soldiers and in the prison of Abu Ghraib, to control the narrative and the reception of the war. ${ }^{3}$ Literary critic W. J. T. Mitchell contends that photographs were exploited to shock and traumatize the enemy, providing "images meant to appal and demoralize, images designed to replicate themselves endlessly and to infect the collective imaginary of global populations." ${ }^{4}$ This observation underscores the 
ideological underpinning of all war images, which urges us to question their use in documentaries, for there seems to be an oxymoronic contradiction in the association of the terms "war" and "documentaries": the "impression of authenticity" which defines the documentary as a genre, based on the notion of fidelity that resides in the mimetic power of the image, ${ }^{5}$ is undermined by the ideological backdrop that pervades the waging of war. Investigating the war urges an engagement with the facts and the motives behind them, which challenges the documentary's claim to truth.

While the focus on the soldiers' experience anchors the narrative of The War Tapes on their ground activities, the collaboration with Deborah Scranton may stand in the way of an authentic rendering of the war. Contrary to the statement appearing on the DVD cover and advertising The War Tapes as "the first war movie filmed by soldiers themselves," ${ }^{\prime}$ the documentary does not provide unfiltered access to the soldiers' experience insofar as the director constructs a narrative arc through their stories. Internet access at the Anaconda base camp permitted regular contact with the filmmaker whereas the military authorities had the final say over whether the tapes could be forwarded or not - scenes of combat in Fallujah were censored. ${ }^{7}$ Scranton served as editor for The War Tapes, selecting from among 800 hours of raw footage the sequences that were to be included in her ninety-minute film. The images recorded may provide a direct view into ground war operations; however, filmmaker Scranton uses them as primary documents in her own documentary, which explores the impact of the war on the home front. From interviews with relatives who endure the pain of absence to happy reunion scenes taking place on the soldiers' return from the front, The War Tapes highlights the distance between the soldiers' military and civilian life. Scranton also inserts television news extracts in counterpoint to the soldiers' footage, pointing to the discrepancy between the media's representation of the war and the men's views of their own actions. Labelled a "war movie" in the advertising slogans, The War Tapes remediates some tropes of the fiction war films, identifying the soldiers as character types with Post Traumatic Stress Disorder by the end of the documentary.

The overall film offers an intimate portrait of Steve Pink, Mike Moriarty, and Zach Bazzi - three National Guardsmen who joined the New Hampshire Army Reserve and accepted to collaborate with Scranton, embarking her cameras in their one-year long tour of duty with Charlie Company, $3^{\text {rd }}$ Battalion, $172^{\text {nd }}$ Infantry Regiment in the Sunni Triangle. The documentary shapes an informative narrative of the war, using editing to fashion a collective war diary, with each soldier conveying his personal views of the actions he participates in. As a proxy director whose role was limited to giving a list of advice concerning filmmaking, Scranton nonetheless makes her presence felt through editing and musical effects that dramatize some events and undermine selfrepresentation. The War Tapes prompts us to interrogate the ethics of war documentaries, most of which have promoted anti-war goals through the compilation of footage in opposition to media representations of the war since Vietnam.

\section{Portraying the Soldiers through Digital Cameras}

5 The War Tapes significantly merges two narrative threads, opposing the events filmed live to voice-over comments, which articulate reflective views that could have been inscribed in a diary. Digital cameras extend the practice of writing in a diary insofar as they introduce critical distance with the events recorded, which can be reviewed and 
explained retrospectively. From moments of action to moments of respite, the tapes suggest that the soldiers' life on the front is divided according to a double time frame: when engaged in military operations, the men are focused on saving their own lives; when returning to their base, they look back at the ordeals they have just gone through and start processing the events into a narrative of their own. Discussing Vietnam Home Movies, war film scholar Guy Westwell argues that the "movies made by these amateur filmmakers provided a way of coping with the experience of the war and, upon returning home, a way of communicating that experience to their friends and families." While The War Tapes serves a similar purpose, allowing the soldiers to fashion their war stories by representing themselves through the use of digital cameras which they tied to their helmets, Humvee dashboards and gun turrets, the introduction of cameras in the frames is a constant reminder of the film's self-reflexive construction, articulating an awareness of the war as spectacle. While digital cameras give direct access to the soldiers' daily life, they also permit the filmed subjects to consciously represent themselves, for the display screens allow them to see how they look and even to delete the most unflattering shots.

6 Rather than write diaries and letters as the Civil War soldiers did in the nineteenth century, today's soldiers send emails, tweet messages, and talk to cameras. Speaking in front of the camera prompts the soldiers to reflect on their war experiences, thereby allowing the camera to substitute itself to the diary many soldiers used in the past to write about their missions. The War Tapes combines the observational stance with the performative mode of documentary filmmaking, as the film cuts from what the soldiers' cameras candidly recorded when tied to their helmets to their self-conscious address at the camera. The sequences shot by the soldiers themselves adopt the formal structures which film scholar Jim Lane associates with autobiographical documentaries:

In the case of autobiographical documentaries, this back-and-forth play between being viewed or framed by the camera and framing that which is viewed is typical. These views of the camera, though heterogeneous as individual shots, are retrospectively ascribed to someone's authority in the world of the film. [...] The views are ascribed to a body. The act of filming becomes an act of scene narration, which is one level of documentary voice. The exchange of the camera becomes an exchange of views, views anchored in an understanding of who people are, both in the documentary narrative and where they are in an actual space. ${ }^{9}$

7 The original footage provided by the military men typically alternates viewpoints, cutting from what they see to their faces. "I'm watching you watching me" comments Moriarty when exchanging looks with Iraqi children who parody his YMCA dance choreography in a moment of innocent complicity that starkly contrasts with the previous sequence detailing all types of attacks that the military undergo on the ground - including Rocket Propelled Grenades (RPGs) and Vehicle Borne Improvised Explosive Devices (VBIED) [15:15]. The film cuts from a long shot of the children standing opposite Moriarty to a high-angle close shot of his face; the distance between the American and the Iraqis is marked visually by the lack of proximity, which the camera enhances when placed behind Moriarty and capturing the figures communicating through body language imitation. Moriarty's self-conscious comments about the unfolding scene pinpoint the sense of otherness that nurtures distrust and suspicion. Framing suggests that the two parties would rather keep at a safe distance from each other while being intrigued by each other. 
Cameras are used as self-reflexive tools which the soldiers exploit to voice their views on the war, posing as soldiers preparing to go to war in the opening sequence - which echoes the characterizing process employed in the credit sequence of Nick Broomsfield's Battle for Haditha (2007). In The War Tapes, Steve Pink, Mike Moriarty, and Zach Bazzi introduce themselves by adopting a self-conscious pose: they look straight at the camera as though addressing the viewers, ostentatiously playing the roles of soldiers. Cross editing allows a diversity of portraits to emerge among the military unit, which undermines the notion of uniformity and conformity among the Army. Pink confesses he made "a rash decision" when enlisting whereas Moriarty recalls that he called a recruiter after visiting Ground Zero in the wake of the 9/11 attacks. Bazzi voices a critical view, pointing to the patriotic myth that many soldiers seem to endorse when accounting for their enrolment, which is illustrated by Moriarty himself and the embedded footage of his filming the smoking ashes of the World Trade Centre. Bazzi's cultural background as a youth who grew up in Lebanon in the Middle East before immigrating to the United States makes him more critical of the army's procedures. His speaking fluent Arabic allows him to connect with the local population and to overcome a language and culture barrier that leads to tragic misunderstandings as he explains in the film, evoking the example of hand signs used by American soldiers to demand Iraqi drivers stop their cars when coming close to a roadblock. This gesture is interpreted as a greeting by Iraqis, who run the risk of getting shot by panicking soldiers when failing to comply with their orders. Bazzi does not systematically view the local civilians as potential threats in opposition to Moriarty: the first talks to children whereas the latter views them as a possible source danger, expressing the paranoiac state of mind which is born out of guerrilla fighting. ${ }^{10}$

9 Cameras seem to nurture this distrust among the military themselves as they view them as another possible threat. When Pink pans the military bunk beds in the barracks of his military base in New Hampshire, he provokes hostile reactions on the parts of other infantrymen who voice their annoyance at the intruding camera gaze. "We're not supposed to talk to the media," one of them observes, eschewing Pink's inquisitive glance. "I'm not the media" he retorts [04:00], which suggests the ambiguity of the role taken by the infantrymen as cameramen whose lack of professionalism may reduce the Iraq war tapes project to a home movie. Pink, however, comments on his previous experience with filmmaking during and after his college years, which aroused his awareness of journalistic practices: “I could tell there isn't any way you can truthfully tell a story without putting a slant on it." [5:00] Equipped with digital cameras, which they conspicuously display in front of other military men, the soldiers of The War Tapes are aware that they are participating in a project that extends beyond the family realm. This awareness politicizes their comments in opposition to the statements presented in the Vietnam Home Movies, which framed the war through the visual idiom of home movies according to Guy Westwell. ${ }^{11}$ The author argues that the Vietnam tapes were filmed for domestic consumption, which led the actors to deflect attention away from the war itself to reassuring activities on the military base. The mobility of digital cameras undermines the home movie approach in The War Tapes; their omniscient presence is made visible through shaky movements that testify to the dangers surrounding the soldiers on an everyday basis both inside and outside the military camp. Pink points out the exact spot for the camera in the Humvee turret ("It's the mark for the camera right here" [13:50]) and later films another soldier holding a camera in his hand [15:34]. The war being fought is also being filmed. 


\section{Narrating the War through the Soldiers' Voice} to convey different points of view and to fashion a narrative that unveils her commitment to an anti-war message. While many critics deem that Scranton remains neutral as regards the war message endorsed by the film, a close analysis of editing points to the opposite. The filmmaker enhances the soldiers' political comments, which betray a measure of cynicism on their parts as they realise the discrepancy between their expectations prior to deployment and the nature of their everyday missions on Iraq. Television screens are recurrent features in the soldiers' footage, creating a miseen-abyme in the documentary insofar as the digital cameras capture diverging attitudes around the television set. On the eve of departure for Iraq, the soldiers watch NBC news presenter declare: "It was a historical moment for Iraq today. A temporary constitution was signed, a first step for the elections in summer and a major accomplishment for the US of what is expected to be a long and difficult path." The camera pans around the room, spotlighting the men's different responses in the face of the announcement: some watch television with an air of satisfaction whereas others play chess in a state of indifference. Snippets from a private conversation can be overheard: "Daddy's got to go to work. Why? Just because." [09:30] The war's objectives are hardly translatable in terms of family life, which the blanks in the phone conversation reveal. The scene enhances the deception of the media's discourse and the ideological framing of the war, which cannot be remediated in an intimate discussion.

a narrator, Scranton emphasizes the absurdity of the war through the editing process, which lingers on moments of inaction when the soldiers are left on their own dealing with their fears for what might happen. The film cuts from a home sequence showing how Moriarty's wife and children cope with the absence of the man from his home to his performing his duty on the front: the filmmaker sheds light on the man's fatherly role by connecting the two sequences through a focus on the children. Moriarty interrogates the goals of his daily missions, observing the surreal aspect of waging ground war in a civilian quarter as children walk away from school:

Here we are in a fighting position with machine guns and Mark 19s. But this is actually someone's backyard right below us. There is this little boy that plays there. He's kind of wandering, talking to himself and torturing his little chicken just over there. This little kid is in a world of his own, surrounded by all this stuff. Funny little kids in the middle of a war zone. I just hope they don't turn bad as they get older as many of them do.

His camera emphasizes the distance between the warrior's attitude and the quiet, innocent landscape he is scrutinizing: the long-shot framing expresses his inquisitive, suspicious look at the local population whom the soldiers view as possible threats.

Editing further heightens the sense of threat in the face of imminent danger that cannot be controlled. Scranton fast-forwards the film to convey the tense, repetitive routine of Humvee patrolling the roads under the stress of random attacks [25:00]. The one-minute sequence aptly connotes the soldiers' vulnerability to external assaults and the sense of alienation that isolates them from their immediate surrounding. The editor tampers with the original footage to build up the risks that the characters face: music adds tension to the soundtrack-a mix of original sounds of a horn beeping and men crying out at the bad traffic. Moriarty's voice-over recalls the nerve-wracking

InMedia, 4 | 2013 
drive, which the film conveys by changing the film speed, thereby introducing a subjective dimension that illustrates the soldier's stress and self-imposed discipline: "You almost had to have a false sense of security in this business." The film slows down when the traffic blocks the Humvee, connoting unpredictable looming danger associated with a delayed flight. After his unit takes fire when overtaking a line of trucks on the road, Moriarty can be heard: "If you didn't have any faith you'd probably have a very hard time living that way everyday" [26:52]. The Humvee races down the road, suggesting the soldier's desire to reach his destination alive. The fast-forwarded sequence translates the emotional intensity of the drive, evoking the highly subjective experience of the soldiers' daily ground missions. Film form stresses mood and tone, which makes performative documentaries all the more compelling according to film critic Bill Nichols:

They want us to feel on a visceral level more than understand on a conceptual level. Performative documentaries intensify the rhetorical desire to be compelling and tie it less to a persuasive goal than an affective one - to have us feel or experience the world in a particular way as vividly as possible..$^{12}$

Scranton explains the stress of the Iraq war through the frightful drive that is part of a never-ending routine in the film. The documentary's focus on driving through IED target zones generates a sense of repetition, which The Hurt Locker (Kathryn Bigelow, 2008) turns into a loose structure, suggesting the aimlessness of the American military occupation in Iraq. ${ }^{13}$ Editing creates a similar effect in The War Tapes, simultaneously allowing the soldiers to emerge as positive characters whose individual courage stands out. The juxtaposition of sequences filmed in New Hampshire and in Iraq pinpoints the divide between civilian and military life, underscoring the extraordinary situations faced by the ordinary men.

Although Scranton provided space for the soldiers to gain a voice in the war, she also portrays them through the conventions of war films. Guy Westwell defines the "noble grunt' film as a subgenre that acknowledges the "war is hell" paradigm while showing the "work is shouldered in good faith and with positive results." ${ }^{14}$ In The War Tapes, the tight focus on the individual fighting men draws attention to the emotional path each of them follows: Moriarty's commitment to Iraq stems from his desire to shake off a state of depression, which he refers to in his emails; Bazzi's mother believes her son looks for a masculine identity figure by running away from her into the Army; Pink confesses that he was striving for meaning after college. The film highlights the transformation that the war produces on each of them: the confrontation to death has a redeeming power and accounts for the ambiguity of the film's political message. The ideological background to the war becomes secondary to the individual situation embodied by each man.

The myth of the war as noble and necessary is nonetheless put to the test through the soldiers' frustrated and powerless gaze at the spoils of the military industrial complex ${ }^{15}$ - represented by the cemetery of broken vehicles which Moriarty visits with his camera [56:00]. The lines of decaying vehicles echo the long lines of trucks blocking the roads of Iraq, providing a symbol for war profiteering. This provokes heavy criticism from the witness soldiers who have no illusion as to the economic interests they are serving, especially when the Army is charged $\$ 56$ for the use of two trays at the lunch counter. Moriarty explains that "our primary mission is convoy security. We go out everyday to the KBR/Halliburton truck yard, we escort their convoy to wherever ... and we take one back," whereas Pink contends that "the KBR trucks are more of a target than we are." 
Both agree to the futility of their task insofar as the soldiers risk their lives to protect the assets of giant corporations, which take advantage of the privatization of the services within the Army to increase their profits. Sergeant Duncan Domey, who provided original footage but whose portrait is not developed in the film, further argues: "We're moving cheese. Cheese, food, soda, paper, supplies and fuel too." The word "cheese" epitomizes the system of war profiteering in the soldiers' mouth, connoting their frustration at the money-making venture which the war in Iraq represents for some corporations whose assets the soldiers are expected to defend and to risk their lives for. Squad leader Kevin Shangraw depicts the extent of war privatization by filming all the shops run by KBR/Halliburton at the Anaconda base: "Take every store in your town, every gas station, police department, fire department, and let it all be run by one company. I mean, that's basically what they do. They have their hand in anything you can think of. KBR runs all our chow halls" [24:00].

Communication scholar Jane Chapman underscores that performative documentaries prompt the filmed participants to actively fashion the narrative of their own stories, for they self-reflexively use the power of the camera to articulate personal and political dilemmas: "The participants seem to be generating their own cinematic text, rather than being guided. This gives the impression that they are integral to the text and to the production device, rather than merely being recorded by it." ${ }^{16}$ In The War Tapes, the military cameramen stage themselves while depicting their life on the front. Pink speaks to the camera to explain that part of his work consists in providing security for septic waste trucks, which Bazzi interprets humorously by addressing the camera as if he were a reporter presenting a scene for the media. The mise-en-scene orchestrated by Bazzi himself emphasizes the irony of the situation, for he behaves as a witness to an event that he wishes to draw attention to: standing in the foreground, he comments on the waste truck dumping dirty water in the ditches behind him. "We are bringing democracy and vegetation to Iraq. You can even see a small rainbow!" he observes in a self-derisive manner, mocking his own role as a soldier whose work should be to fight for something greater. The film then cuts to a television extract of President Bush declaring on April 28, 2004: "This is a day of great hope for Iraq. The Iraqi people have left behind one of the worst regimes on the Middle East and their country is becoming the world's newest democracy." Editing highlights the distance between the commander in chief and the grunts, whose experience of democracy in Iraq is restricted by the implication of private enterprises and the guerrilla war tactics represented by Improvised Explosive Devices (IEDs), Vehicle Born Improvised Explosive Devices (VBIEDs), and Rocket Propelled Grenades (RPGs). The use of digital cameras politicizes the documentary by making the soldiers look at the war through the viewfinder of their cameras. Not only does the frame reduce their vision to their individual fights, highlighting the distance between the political discourses heard on television and their ground experience, but it also conveys the men's intimate experience with death through repeated mortar attacks. Digital cameras build a fragmentary view of the war, which pinpoints the isolation of the men on the ground. ${ }^{17}$

\section{Documenting the Trauma of War}

In her seminal study of Issues in Contemporary Documentary, Jane Chapman devotes several pages to The War Tapes and emphasizes that the digital technology used by the 
filmmaker permitted her to gain direct access to "'hotwash', a military term for an immediate reaction after an event, a reaction missing from official military report that results in a softened and professionalized overview of occurrences in the field." 18 Rather than highlight the immediate responses to the events witnessed, I argue that the film enhances their "belated impact" which trauma theorist Cathy Caruth links to the definition of post-traumatic stress disorder:

The experience of trauma, the fact of latency, would thus seem to consist, not in the forgetting of a reality that can hence be fully known, but in an inherent latency within the experience itself. The historical power of the trauma is not just that the experience is repeated after its forgetting, but that it is only in and through its inherent forgetting that it is first experienced at all. ${ }^{19}$

19 The War Tapes underlines the soldiers' belated response to the horror scenes they attend. Through the use of retrospective comments expressed in voice-over, the film underscores the time gap between what is seen and what is verbalized afterwards. After an IED attack takes place outside the military base, Moriarty goes back to the dark barracks and ponders:

About an hour of being back here you start thinking about what you've just been through, there's a guy saying prayers at the table and we all got choked up, it comes down like a ton of bricks, how close you came to never see your family again, never see my kids again...

20 His camera captures the figures of the men sitting in silence and looking at photographs of dear ones in the dark. Moriarty's face appears in a close-up on screen; however, the night-vision image gives him a ghostly appearance, which is reinforced by the use of a voice-over: his voice can be heard although his lips do not move, thus turning belatedness into a visual effect. Editing conveys the distance between Moriarty's reflections as he looks back at the events of the day and the events he tries not to remember by focusing on the photographs of his children.

21 The War Tapes repeatedly uses the soldiers' voice-over commentaries, most of which were recorded after the soldiers' return to New Hampshire, ${ }^{20}$ thereby pinpointing the distance between the events taking place and the soldiers' memory of them. Belatedness is further signified by Pink's voice-over reading of his war diary: Scranton interweaves close-ups on the handwritten pages and camera footage of the events they refer to, thereby establishing a link between the filmed events and their subsequent narrativization. The film proceeds to a form of suture by using the retrospective narrative as a commentary that tries to introduce order in the confusion of the filmed events. The visuals signify the haunting power of war images, illustrating the words that convey the shock of the traumatized subject. Scranton's editing is conspicuous as she uses a dissolve from Steve Pink's written diary to the footage his words refer to. The voice-over utters the sentences as the camera pans them in close-ups, suggesting that the film uses re-enactment on the part of the soldiers. Rather than convey the distance with the narrated events, the lingering voice-over enhances the power of the haunting images in the present.

Following the opening sequence, Pink's voice-over starts reading the words of his journal, which superimpose on his facial features: "I want to kill. I may have already killed one or some of these bastards with the Mark 19 Grenade." The voice-over gives us access to interiority; however, it is also used as a self-reflexive tool to comment on the events witnessed and the recorded images. The camera allows the soldier to recount and to verbalize what he saw, including the horrors that shocked him: 
Today was the first day I shook a man's hand that wasn't attached to his arm. I was the first one there and immediately clamped Reggie's brachial artery. I looked down and he had his hand dangling from the exposed bone that used to be his elbow, like a child's safety clipped mitten dangling from their winter coat. If I play the odds one of us will die before the tour is over. It's something that I don't like to think about.

Trauma consists in the revival of an event, its re-enactment, which the film underlines by showing footage that echo such words. Editing relates the sequence filmed on the spot by a hand-held camera investigating the remains of a bombed car with Steve Pink's journal, suggesting that the scene witnessed cannot easily be forgotten. The footage testifies to the soldier's physical presence on the scene as his shadow is cast on the ground that his camera focuses on, especially on the blood puddles spreading around. The unstable camera zooms on the burnt corpse of a man dangling out of a bombed car, while the voice of the soldiers depicts the facts: "This is the scene north. They just removed a body or half a body. I think there was nothing left from the abdomen down." The scene is given a context by the voice-over, reading from Pink's journal once again, suggesting the time lapse between the events seen and their enduring power on the mind:

I remember giving three IV's, bandaging several wounded. Soldiers sitting in the corner of a sandbag wall shaking, screaming. Medics who were terrified and couldn't perform. I later heard that Iraqi casualties were not to be treated in Taji. They can work on the post for pennies but can't die there. They've got to die outside. If one of those incompetent medical officers told me to stop treatment I would have slit his throat right there.

Cathy Caruth draws on Freud's analysis of shellshock when suggesting that traumatic experience "is an experience that is not fully assimilated as it occurs." ${ }^{21}$ The film emphasizes the fact that the voice-over commentary is disconnected from the visual narrative, positing the impossible narrativization of the events as they happen and are witnessed by the soldiers.

Quite interestingly, the film opens with a sequence that crops up again in the narrative [39:00], using the same quotes from Pink's journal in the commentary: "Every once in awhile as we're driving down the road or creeping along a patrol, I have a reoccurring epiphany - this is happening and will have a lasting impact on me for the rest of my life." The repetition of the same images and the same sentence allows the film to convey the sense of trauma which, according to sociologist Kai Erikson, is marked by haunting images which prompt the traumatized individual to relive the past:

A chronicler of passing events may report that the episode itself lasted no more than an instant - a gunshot, say - but the traumatized mind holds on to that moment, preventing it from slipping back into its proper chronological place in the past, and relives it over and over again in the compulsive musings of the day and the seething dreams of night. ${ }^{22}$

Scranton uses editing to explain the impact of traumatic war events: the opening sequence is replicated again in the middle of the film, suggesting the enduring power of an event that has not been assimilated. The footage used to articulate trauma refers to the moment when Pink's platoon enters Fallujah: the sequence opens with a long shot of the city from which clouds of smoke rise up. A sense of confusion quickly seeps in as we view the scene through a camera tied to one of the soldiers' helmet: the men are suddenly under fire and start running away for protection; the recorded footage restricts our view to shaky images that betray the panic that strikes the men who can 
neither identify the shooters nor locate the exact place of their hiding aggressors. The sound of pounding gunshots conveys the sense of vulnerability and terror among the assailed men. The pace of action does not seem to allow them to understand or to grasp the whole scene. The setting looks deserted; three men throw a grenade in what looks like an abandoned house, when a voice cries out of the blue: "Sergeant Smith's down!"

While The War Tapes provides a raw record of dangerous actions, during which the soldiers are more preoccupied with saving their own lives than posing in front of the camera, it also offers intimate moments with the soldiers as they discuss their fears or meet up with their families. The end of the film focuses on their return to civilian life through interviews with their loved ones, who testify about the destructive impact of trauma. Pink's girlfriend mentions his nightmares whereas Moriarty's wife recalls his extreme reaction when he unexpectedly pulled the steering wheel fearing she had not spotted a pedestrian who was about to cross the street. The event resonates with the embedded sequence of an Iraqi woman being run over by his Humvee, which keeps haunting him long after his return to New Hampshire. The film gives insight into the symptoms of post-traumatic stress disorder, which Caruth identifies as follows:

While the precise definition of post-traumatic stress disorder is contested, most descriptions generally agree that there is a response, sometimes delayed, to an overwhelming event or events, which takes the form of repeated, intrusive hallucinations, dreams, thoughts or behaviors stemming from the event, along with numbing that may have begun during or after the experience, and possibly also increased arousal to (and avoidance of) stimuli recalling the event..$^{23}$

The War Tapes conveys the subjective experience of the war by blurring the boundaries between two documentary modes: the soldiers participate in the process of filmmaking, inviting the viewer and the editor to observe the war through their eyes. The whole process produces intimacy and draws sympathy for the men as Scranton's editing crafts a narrative of the war that emphasizes the emotional impact of fighting on the individual soldiers and undermines the political comments of her characters.

Although The War Tapes formulates a critique of the Iraq war, pointing to the unethical conduct among profiteering companies, it eschews an overtly anti-war message by siding with the soldiers whose characterization sheds light on qualities of bravery and selflessness that transcend the gross abuses of war profiteers. Guy Westwell argues that "contemporary war cinema's resolute focus on traumatized young men [which] also enables a redemptive narrative of therapeutic healing to be brought to bear." ${ }^{44}$ The soldiers are portrayed as unordinary characters, whose commitment to patriotic values has a redeeming power. Identified with the bodies of the military, the cameras enhance the perception they have of themselves as possible targets, drawing sympathy for their plight. The film's documentary value resides in the power of digital cameras to overcome the distance of an external eye; the horror the soldiers witness is integrated into their everyday life on the front and at home. The voice-over endeavours to reconcile the narrative gap between the present and the past, and the images and the soundtrack - a void that signifies the lingering sense of trauma.

The soldiers' critical voices nonetheless lose power and meaning as they are interwoven in a narrative fashioned by the filmmaker, who is eager to enhance the emotional impact of the war and its haunting effect. As the soldiers retrospectively comment on their Iraqi experience, Scranton uses editing to highlight the physical and mental traces of the conflict on the men whose return to civilian life is forever compromised. The documentary does not romanticize the soldiers' war memories like 
Vietnam Home Movies, focusing instead on the signs of post-traumatic stress disorder that convey their difficult readjustment to civilian society. The War Tapes thus endorses the prevailing discourse on "The War on Terror," making the soldiers appear either as victims (Pink, Moriarty) or heroes (Bazzi). Cultural studies scholar Martin Barker argues that the reference to post-traumatic stress disorder draws attention away from acts of war and places the emphasis on the soldiers instead. According to him, this shift in focus is the incipient message of a "toxic genre":

With the smell of science and the promise of remedies, PTSD has come to function as a key metaphor for America inspecting itself within safe margins. What does it achieve? It offers soldiers a self-justifying account of their situation. It 'explains' abuses as unintentional outbursts. It generates positive-smelling narratives. It helps making suffering 'American.' ${ }^{25}$

31 Try as she might to recover the soldiers' authentic experience by giving authorial power to the men who discuss their actions while filming, Scranton remediates their footage in a narrative that espouses the dominant view of the war. The soldiers were given some measure of agency through the cameras they were entrusted with; however, their voices are subdued by the filmmaker's editing, interfering with the war narrative they may have produced if they lacked Scranton's guidance. Through remediation, Scranton appropriates their stock footage in a story that contributes to constructing the collective memory of the Iraq war, shedding light on notions of American sacrifice and suffering. The pain they feel long afterwards redeems the soldiers' participation in tragic events - such as the killing of a civilian woman whose body was run over by a speeding Humvee on an Iraqi road in the dark of night. Complicit with the ideological lens as identified by Barker, is the personal lens through which the war stories are told throughout the documentary. The videos capture the sense of guilt that lingers long after returning to the homeland, thereby allowing the viewer to share in the soldiers' suffering.

\section{BIBLIOGRAPHY}

Bacevich, Andrew J. The New American Militarism: How Americans Are Seduced by War. Oxford: Oxford University Press, 2005.

Barker, Martin. A 'Toxic Genre': The Iraq War Films. London: Pluto Press, 2011.

Caruth, Cathy. Unclaimed Experience, Trauma, Narrative, and History. Baltimore: The John Hopkins

University Press, 1996.

Chapman, Jane. Issues in Contemporary Documentary. Cambridge and Malden: Polity Press, 2009.

Clover, Joshua. “Allegory Bomb.” Film Quarterly, 63 (2), 9.

Kai Erikson. "Notes on Trauma and Community." In Trauma: Explorations in Memory, edited by Cathy Caruth, 183-199. Baltimore, MD: John Hopkins University Press, 1995.

Lane, Jim. The Autobiographical Documentary in America. Madison, Wisconsin: The University of Wisconsin Press, 2002. 
Mitchell, W. J. T. Cloning Terror, The War of Images, 9/11 to the Present. Chicago \& London: The University of Chicago Press, 2011.

Nichols, Bill. Introduction to Documentary. Bloomington, Indiana: Indiana University Press, 2001, 2010.

Strangelove, Michael. Watching Youtube: Extraordinary Videos by Ordinary People. Toronto, Buffalo, London: University of Toronto, 2010.

Westwell, Guy. "The Domestic Vistion of Vietnam Home Movies." In The Image and the Witness, Trauma, Memory and Visual Culture, edited by Frances Guerin and Roger Hallas, 143-155. London \& New York: Wallflower Press, 2008.

\section{Webography}

http://thewartapes.com/the_film/TWT_PressNotes_10_27_final.pdf <accessed on March 26, 2013>

\section{NOTES}

1. Michael Strangelove observes that Youtube permitted the viral spread of such videos: "While videos made by insurgents remain 'underground' on Youtube, it is easy to locate images of insurgents being killed in Iraq by occupying forces. Also, videos of IED attacks on occupying forces within Iraq are widespread and attract millions of viewers. In May 2007 there were approximately 2,300 videos tagged with the letters 'IED'. By November 2009 this number had swelled to 9,620." Michael Strangelove, Watching Youtube: Extraordinary Videos by Ordinary People (Toronto, Buffalo, London: University of Toronto, 2010), 152.

2. "Stored in box rooms, garages and attics, these amateur films formed a haphazard archive that remained untapped until the mid-1980s when a commercial video production company, Vietnam Archives Inc., collected and distributed them under the title Vietnam Home Movies." Guy Westwell, "The Domestic Vision of Vietnam Home Movies" in The Image and the Witness, Trauma, Memory and Visual Culture, eds. Frances Guerin and Roger Hallas, (London \& New York: Wallflower Press, 2008), 143.

3. Mitchell points to the photo of Corporal Edward Chin hooding the head of Saddam's statue with an American flag on April 10, 2003, as a case of visual miscommunication: "The flag-hooded Saddam became, like the images of his capture and execution, a symbol of outrage and shame to the Arab masses. Like many other images of American triumphalism during the invasion of Iraq, it helped to mobilize Iraqi nationalism and to recruit jihadists from other Arab countries [...]. W. J. T. Mitchell, Cloning Terror, The War of Images, 9/11 to the Present (Chicago \& London: The University of Chicago Press, 2011), 90-91.

4. W. J. T. Mitchell, Cloning Terror, 2.

5. Bill Nichols, Introduction to Documentary (2001; Bloomington, Indiana: Indiana University Press, 2010), xiii.

6. See the press notes: http://thewartapes.com/the_film/TWT_PressNotes_10_27_final.pdf $<$ accessed on March 26, 2013>

7. Jane Chapman, Issues in Contemporary Documentary (Cambridge and Malden: Polity Press, 2009), 83.

8. Westwell, “The Domestic Vision of Vietnam Home Movies", 143.

9. Jim Lane, The Autobiographical Documentary in America (Madison, Wisconsin: The University of Wisconsin Press, 2002), 30. 
10. Moriarty observes Bazzi sympathize with local Iraqi youths and ironically comments: "You see Sergeant Bazzi communicate with local people. I think he might be a spy. I don't quite trust him. He's playing against us. You see! The deal is sealed! A handshake! A fraternity! What a traitor!" Bazzi's ability to speak with the local population makes his otherness stand out among the military.

11. "The institutional space of the Army - regimented, strictly hierarchical and bureaucratically impersonal - is de-emphasized in favour of an imaginary space modelled on the family. The Army as structure is replaced with the all-male unit located around the interior of the helicopter and the tents in which the men live and where they spend most of their non-combat time. This ensures a tight, nuclear-family-sized focalisation for the home movies and acts as a surrogate for a more conventionally conceived home." Westwell, "The Domestic Vision of Vietnam Home Movies ", 146.

12. Nichols, Introduction to Documentary, 203.

13. Joshua Clover, "Allegory Bomb" in Film Quarterly, 63 (2), 9.

14. Westwell, "The Domestic Vision of Vietnam Home Movies", 26.

15. Andrew J. Bacevich argues that "Americans in our own time have fallen prey to militarism, manifesting itself in a romanticized view of soldiers, a tendency to see military power as the truest measure of national greatness, and outsized expectations regarding the efficacy of force. To a degree without precedent in US history, Americans have come to define the nation's strength and well-being in terms of military preparedness, military action, and the fostering of (or nostalgia for) military ideals." Andrew J. Bacevich, The New American Militarism: How Americans Are Seduced by War (Oxford: Oxford University Press, 2005), 2.

16. Chapman, Issues in Contemporary Documentary, 106.

17. In Standard Operating Procedure (2008), Errol Morris strives to recover the stories behind the digital photographs that spurred the Abu Ghraib scandal in 2004. The filmmaker highlights the incomplete narrative the snapshots encapsulate by relating to the soldiers' retrospective accounts. Using a rigid mise-en-scene technique known as the interrotron, he however fails to overturn the implicated soldiers' image as "monsters". Scranton empowers the soldiers whom she allows to perform themselves whereas Morris enhances his interviewees' complacent attitude in a setting that seems to replicate the oppressive conditions of the prison. See XXX.

18. Chapman, Issues in Contemporary Documentary, 82.

19. Cathy Caruth, Unclaimed Experience, Trauma, Narrative, and History (Baltimore: The John Hopkins University Press, 1996), 17.

20. In the interviews added in the bonus section of the DVD, Pink explains that he read from his diary for the film after his return to New Hampshire.

21. Caruth, Unclaimed Experience, 5. The writer further explains: "In its general definition, trauma is described as the response to an unexpected or overwhelming violent event or events that are not fully grasped as they occur, but return later in repeated flashbacks, nightmares, and other repetitive phenomena. Traumatic experience, beyond the psychological dimension of suffering it involves, suggests a certain paradox: that the most direct seeing of a violent event may occur as an absolute inability to know it; that immediacy, paradoxically, may take the form of belatedness. The repetitions of the traumatic event - which remain unavailable to consciousness but intrude repeatedly on sight - thus suggest a larger relation to the event that extends beyond what can simply be seen or what can be known, and is inextricably tied up with the belatedness and incomprehensibility that remain at the heart of this repetitive seeing." Idem, 91-92

22. Kai Erikson, "Notes on Trauma and Community" in Trauma: Explorations in Memory, Cathy Caruth ed., Baltimore, MD: John Hopkins University Press, 1995), 185.

23. Cathy Caruth, "Introduction" in Trauma: Explorations in Memory, 4. Kai Erikson further explains: "Traumatized people often scan the surrounding world anxiously for signs of danger, breaking into explosive rages and reacting with a start to ordinary sights and sounds, but at the 
same time, all that nervous activity takes place against a numbed gray background of depression, feelings of helplessness, and a general closing off of the spirit, as the mind tries to insulate itself from further harm. Above all, trauma involves a continual reliving of some wounding experience in daydreams and nightmares, flashbacks and hallucinations, and in a compulsive seeking out of similar circumstances." Kai Erikson, "Notes on Trauma and Community", Idem, 184.

24. Westwell, "The Domestic Vision of Vietnam Home Movies", 31.

25. Martin Barker, A ‘Toxic Genre’: The Iraq War Films (London: Pluto Press, 2011), 98-99.

\section{ABSTRACTS}

Not only do digital cameras allow ground soldiers to film the war as they live it, but they also give them access to self-representation. Interestingly, digital cameras have often replaced the war diary, permitting the soldiers to look back at the events of the day and to retrospectively discuss what they went through. Film director Deborah Scranton used the footage provided by a few soldiers whom she distributed digital cameras to fashion an original narrative of the Iraq war in The War Tapes (2006). Her film interweaves various types of footage, combining the soldiers' authorial voice with her own. As editor and narrator, Scranton enhances the distance between life on the front and back in civilian society. Through a close examination of the produced film, this article aims to assess the impact of digital cameras on the representation of war in documentary filmmaking.

\section{INDEX}

Keywords: Iraq war, documentary, digital media, soldiers, Vietnam War

\section{AUTHOR}

\section{DELPHINE LETORT}

Delphine Letort is Senior Lecturer in the English Department at the University of Le Mans (France) where she teaches American civilisation and film studies. Her research explores the relationship between history, memory, and film in American fiction and nonfiction cinemaincluding war documentaries and African American television films. She studies the ideological construction of stereotypes and the politics of representation developed in Hollywood productions. 